\title{
Corrigenda van drukproef verwerkt
}

\section{Tyconius' Apocalypse Commentary, its Reconstruction, and its Significance for Augustine's Doctrine of the Two Cities}

\author{
Johannes van Oort \\ University of Pretoria \\ j.van.oort@planet.nl
}

\section{Summary}

The present article deals with Roger Gryson's reconstruction of Tyconius' lost Commentary on the Apocalypse (CCL 107A), his subsequent French translation of this reconstructed Commentary (CCT 10), and the English translation Tyconius, Exposition of the Apocalypse by Francis Gumerlock, with long introduction and ample notes by David Robinson (FoC 134). After having reviewed the strenghths and weaknesses of each of these publications, the article concludes with a discussion of the significance of Tyconius' Commentary for the question of the origin of Augustine's two civitates doctrine.

Keywords

Tyconius - Apocalypse Commentary - Augustine - Two Cities

\section{New Books on Tyconius' Apocalypse Commentary}

The past years have seen a remarkable interest in Tyconius' Commentary on the Apocalypse. The main result appeared in 2011 when Roger Gryson, after many years of preparatory work, published his reconstruction of the lost Commentary. ${ }^{1}$ In the same year, he complemented this major achievement with a French translation of Tyconius' reconstructed work. ${ }^{2}$ Both books contain long introductions and supplementary annotations: in case of the text edition, there are more than 100 pages of 'Notes complémentaires', while the translation has hundreds of footnotes along with an apparatus indicating the innumerable biblical quotes and allusions. Although there is some overlap between these introductions and notes, each of the publications nevertheless has its own scopus and distinctive

\footnotetext{
${ }^{1}$ Tyconï Afri Expositio Apocalypseos, accedvnt eivsdem Expositionis a qvodam retractatae Fragmenta Tavrinensia, cura et studio Roger Gryson (Corpvs Christianorvm, Series Latina CVII A), Turnhout: Brepols Publishers 2011, 387 pp., ISBN 978-2-503-54062-7, € 195 (hb).

${ }^{2}$ Tyconius, Commentaire de l'Apocalypse. Introduction, traduction et notes par Roger Gryson (Corpvs Christianorvm in translation 10), Turnhout: Brepols 2011, 220 pp., ISBN 978-2-503-54068-9, € $50.00(\mathrm{pb})$.
} 
value. In the wake of these groundbreaking French books, two young American scholars produced their English translation of Tyconius' reconstructed Commentary, which appeared in the famed and widely diffused series The Fathers of the Church. ${ }^{3}$ This translation, too, is accompanied by an ample introduction and many elucidating notes.

The present article aims at critically introducing these recent publications and posing some additional questions. The main issues to be further discussed are the following: (1) How reliable is Gryson's reconstruction and how does he reach his result - in other words: what about his modus procedendi?; (2) Does Gryson's reconstruction shed new light on the origin of Augustine's two civitates doctrine?

\section{The Problem of Tyconius' Apocalypse Commentary}

By way of introduction, we may briefly consider the multifaceted problems that surround Tyconius' lost Commentary. Apart from the possibility of some early (though anonymous) uses of this work, ${ }^{4}$ we have the rather extensive notice by Gennadius of Marseilles (fl. ca. 470), who purports to have read the Commentary and relates some important views from it. ${ }^{5}$ In addition to Gennadius, the Commentary has been read and extensively used by later interpreters of St. John's Apocalypse, such as Caesarius of Arles ( $† 542)$, Primasius of Hadrumetum ( $\nmid$ ca. 560), Cassiodorus († ca. 580), the Venerable Bede († 735), and-most extensively and perhaps most markedly-by the Spanish priest and abbot Beatus of Liebana (late eighth century). Supplementary to these sources, there are the rather recently found fragments from Budapest, ${ }^{6}$ as well as the earlier discovered-but not so genuine, because paraphrased-fragments from a Bobbio manuscript now in Turin. ${ }^{7}$ Simply stated, one may be able to reconstruct Tyconius' Commentary by

\footnotetext{
${ }^{3}$ Tyconius, Exposition of the Apocalypse. Translated by Francis X. Gumerlock; with introduction and notes by David C. Robinson, Washington, D.C.: The Catholic University of America Press 2017, xv + 207 pp., ISBN 978-0-8132-2956-0, \$ 39.95 (hb with jacket).

${ }^{4}$ Perhaps by Jerome, in his non-chiliastic edition of the Apocalypse Commentary of Victorinus of Pettau, and by Augustine, who early in his ecclesiastical career changed his chiliastic reading of Apoc. 20 (cf. s. 259, ca. 393) into an anti-chiliastic one such as extensively expressed in ciu. 20. From Augustine's doctr. chr. 3,42 we can be sure that he read Tyconius' Commentary.

${ }^{5}$ Gennadius, vir. ill., 18 (ed. Richardson, 68-69): 'Exposuit et Apocalypsin Iohannis ex integro, nihil in ea carnale, sed totum intelligens spiritale. In qua expositione dixit angelicam stationem corpus esse. Mille quoque annorum regni in terra iustorum post resurrectionem futuri suspicionem tulit; neque duas in carne mortuorum resurrectiones futuras, unam iustorum et alteram iniustorum, sed unam et insemel omnium in qua resurgent etiam abortivi, deformati, ne quid humani generis deformatum et animatum substantia intereat, ostendit. Distinctionem sane duarum resurrectionum ita facit, ut primam, quam iustorum Apocalypsis dicit, credamus modo in ecclesiae incremento agi, ubi iustificati per fidem a morticinis peccatorum suorum per baptismum ad vitae aeternae stipendium suscitantur, secundam vero generaliter omnis hominum carnis'. ${ }^{6}$ R. Gryson, 'Fragments inédits du commentaire de Tyconius sur l'Apocalypse', RB 107 (1997) 189-226.

${ }^{7}$ F. Lo Bue (ed.), The Turin Fragments of Tyconius' Commentary on Revelation, Cambridge: CUP 1963 (T\&S, NS VII, prepared for the press by G.G. Willis).
} 
starting from the undisputed genuine remains, such as the Budapest Fragments, the Turin (though catholically adapted) Fragments, and those passages explicitly attributed by later writers to Tyconius. ${ }^{8}$ To these may be added the passages in later commentators who either betray Tyconius' singular way of reasoning coupled with his particular concepts and writing style, as undoubtedly expressed in his Liber regularum, ${ }^{9}$ or passages that explicitly refer to cirumstances from his time and world. ${ }^{10}$ The German scholar Traugott Hahn, for instance, partly basing himself on earlier research by Wilhelm Bousset and making use of Henricus Florez' edition of Beatus, ${ }^{11}$ indicated the passages in Beatus which were clearly borrowed from Victorinus, Apringius, Augustine, Ambrose, Jerome, Isidore of Sevilla, and Gregory the Great. The remaining part of Beatus' Commentary, so he reasoned, could in all probability be ascribed to Tyconius. ${ }^{12}$ One of the remaining problems, however, was (and still is) that Beatus did not always copy Tyconius as slavishly as one would wish for a reliable reconstruction. A further problem is that Beatus seems at times to have misunderstood Tyconius; moreover, Florez' edition of Beatus turned out to be highly unreliable. ${ }^{13}$

\section{Gryson's modus procedendi in Reconstructing Tyconius' Commentary}

In view of all these difficulties, one is eager to see how Roger Gryson proceeded in order to arrive at a reliable reconstruction of 'Tyconius' lost Commentary. In the first part of his CCL edition, he rather extensively explains his modus procedendi. After sketching the present state of the problem (I: 'État de la question', 13-19), he

\footnotetext{
${ }^{8}$ Beda's Expositio Apocalypsis is a fine case in point, because he repeatedly made explicit what he derived from the Donatist's Commentary.

${ }^{9}$ Formerly only available in the masterful edition of F.C. Burkitt, The Book of Rules of Tyconius, Cambridge: CUP 1894 (T\&S III,1), which text has rather recently been reprinted in the series Sources Chrétiennes, accompanied by an introduction, French translation and notes by JeanMarc Vercruysse, Tyconius, Le Livre des Règles, Paris: Cerf 2004.

${ }^{10}$ As we find them in particular in Beatus, who literally copied passages dealing with Africa or the circumcelliones.

${ }^{11}$ Sancti Beati Presbyteri Hispani Liebanensis, In Apocalypsin, ac plurimas utriusque foederis paginas Commentaria, Ex veteribus, nonnullisque desideratis Patribus, mille retro annis collecta, nunc primum edita. Opera et studio R.P. Doct. Henrici Florez (...), Matriti MDCCLXX: Apud Joachim Ibarra. For some reason or another, this edition became very rare (some later researchers speak of only a dozen copies available in libraries), but a copy from the Biblioteca Complutense is now easily accessible on the internet.

${ }^{12}$ T. Hahn, Tyconius-Studien. Ein Beitrag zur Kirchen- und Dogmengeschichte des vierten Jabrbunderts, Leipzig: Dieterich'sche Verlags-Buchhandlung 1900, 10-12.

${ }^{13}$ See already Hahn, Tyconius-Studien, 16-18. Of the many other problems, I indicate only the following ones: What about the numerous concurrences (see the specification in Lo Bue's edition) between, in particular, Bede and the Turin Fragments? Was the Catholic adaptation of these Fragmenta Taurinesia made very early, i.e., even before Caesarius and Primasius? Who composed the Summa dicendorum that Beatus placed before his Commentary? Can we fully adhere to Ramsey's view (see H.L. Ramsay, 'Le commentaire de l'Apocalypse par Beatus de Liébana', RHLR 7 [1902] 419-447) that many texts in Beatus which Hahn ascribed to Tyconius actually go back to Gregory and Isidore?
} 
describes his sources (II. 'Les sources: 1. Les fragments de Budapest; 2. Les fragments de Turin; 3. Les homélies de Césaire d'Arles; 4. Le commentaire de Primasius d'Hadrumète; 5. Les Complexiones de Cassiodore; 6. Le Commemoratorium pseudo-hiéronymien; 7. Le commentaire de Bède; 8. La glose de Cambridge et les textes apparentés; 9. Le commentaire d'Ambroise Autpert; 10. Le commentaire de Beatus de Liébana', 20-73), and finally presents some of the main underlying principles of his edition (III: 'La présente édition: 1 . La reconstitution du commentaire; 2. La reconstitution du lemme; 3. Les divisions', 74-102).

Gryson's 'état de la question' briefly touches upon some main stages of the interesting history of the reconstruction of Tyconius' Commentary: the 1770 edition of Beatus by Florez and the consecutive views of Johannes Haußleiter, Wilhelm Bousset and, above all, Traugott Hahn. From the later researchers who, in some way or another, contributed to a solution of the problem, he particularly mentions the just quoted Ramsay, ${ }^{14}$ Joseph Ratzinger, ${ }^{15}$ Jean-Marc Vercruysse, ${ }^{16}$ Martine Dulaey, ${ }^{17}$ Klauspeter Vogt ${ }^{18}$ and Kenneth B. Steinhauser, ${ }^{19}$ as well as the editors of Beatus' Commentary who came after Florez, i.e., H.A. Sanders, ${ }^{20}$ E. Romero Pose, ${ }^{21}$ A. del Campo Hernández, ${ }^{22}$ and S. Alvarez Campos. ${ }^{23}$ Gryson is not hesitant in his praise or blame: the contributions of Ramsay, Ratzinger, Vercruysse, Dulaey, and Vogt are all highly praised; ${ }^{4}$ for the other scholars he

\footnotetext{
${ }^{14}$ Ramsey, 'Commentaire' (n. 13).

${ }^{15} \mathrm{~J}$. Ratzinger, 'Beobachtungen zum Kirchenbegriff des Tyconius im Liber regularum', REA 2 (1956) 173-185.
}

${ }^{16}$ See n. 9. Curiously, here and in his CCT book, Gryson speaks of Vercruysse's publication as an 'edition' of Tyconius' Liber regularum, although Vercruysse just reprinted Burkitt's edition omitting its extensive and precious apparatus criticus, but with the useful addition of his own numbering of paragraphs and sentences.

${ }^{17}$ M. Dulaey, 'Jérome «éditeur» du Commentaire sur l'Apocalypse de Victorin de Poetovio', REA 37 (1991) 199-236.

${ }^{18} \mathrm{~K}$. Vogt, Untersuchungen zur Geschichte der lateinischen Apokalypse, 2 vols., Diss. Freiburg im Breisgau (typescript) s.a. [1965].

${ }^{19}$ K.B. Steinhauser, The Apocalypse Commentary of Tyconius. A History of Its Reception and Influence, Frankfurt am Main-Bern-New York: Peter Lang 1987.

${ }^{20}$ Beati in Apocalypsin libri duodecim, ed. Henry A. Sanders, Roma: American Academy in Rome 1930.

${ }^{21}$ Sancti Beati a Liebana Commentarius in Apocalypsin, ed. E. Romero Pose, 2 vols., Romae: Typis Officinae Polygraphicae 1985.

${ }^{22}$ In Beato de Liebana, Obras completas y complementarias (Biblioteca de Autores Cristianos, vol. 76-77), Madrid: BAC 2004, vol. II, 52-275.

${ }^{23}$ S. Alvarez Campos, 'Fuentes litterarias de Beato de Liébana', in: Actas del simposio para el estudio de los codices del 'Commentario al Apocalipsis' de Beato de Liébana, I, Madrid: Joyas Bibliográfias 1978, 117-162.

${ }^{24}$ E.g. on Ramsay: 'On admirera la clairvoyance dont fait preuve Dom H.L. Ramsay ... Il ne s'est pas contenté d'enricher considérablement la liste des emprunts identifiés dans la compilation de Beatus. Il a également redressé avec tact, mais sans indulgence, beaucoup d'erreurs de ses devanciers. À propos de la manière dont Beatus a fait entrer Tyconius dans sa compilation, et de la voie à suivre pour reconstituer le texte de Tyconius, en rapprochant Beatus des autres sources disponibles, notamment des fragments de Turin, il a écrit des pages lumineuses, auxquelles il n'y a 
reserves his sometimes harsh criticism. ${ }^{25}$ One may note this criticism in the case of Steinhauser's dissertation in particular: while Gryson in an earlier study applauded Steinhauser for having laid the foundation for a prospective reconstruction of Tyconius' Commentary, ${ }^{26}$ he is now severely blamed. ${ }^{27}$ This 'bipartite' attitude with regard to Steinhauser's work is characteristic of much of the rest of Gryson's introduction and commentary. ${ }^{28}$

Summarizing the possible reconstruction of 'Tyconius' work, Gryson remarks that one should first have the following at one's disposal: a new edition of Bede's Commentary; a new edition of Cassiodorus' Complexiones in Apocalypsin; a new edition of the so-called Commemoratorium de Apocalypsi Iobannis; and a new edition of the recently discovered Cambridge Gloss, in tandem with some closely related texts. He himself did the work in the case of the Venerable Bede, ${ }^{29}$ of Cassiodore's Complexiones, ${ }^{30}$ and of the Commemoratorium and the texts related to the Cambridge Gloss. ${ }^{31}$ Meanwhile, he also provided the editio princeps of the Cambridge Gloss on Revelation discovered by Guy Lobrichon, ${ }^{32}$ a new edition of Victorinus' Commentary, ${ }^{33}$ and even a new dual volume edition of Beatus' Commentary. ${ }^{34}$ All this, so he concludes, will be a sufficient basis for the reconstruction of Tyconius'

pas grand-chose à ajouter. Dès cet instant, du point de vue méthodologique, l'essentiel était dit' (15); on Vogt: 'Le seul ouvrage qui ait vraiment fait progresser notre connaissance du commentaire de Tyconius, dans la seconde moitié du vingtième siècle ...' (16).

${ }^{25}$ E.g. on Sanders: 'le principal mérite est d'être plus accessible que l'édition princeps de 1770; les fautes de collation y sont innombrables ...' (18); on Romero Pose's work: 'se fonde sur la précédente [sc. Sanders], dont elle accentue encore les défauts' (ibidem); A. del Campo Hernández 'a eu tort de faire confiance à S. Alvarez Campos, qui attribue trop facilement au maître africain, dans le commentaire de Beatus, ce dont il n'a pas trouvé la source ailleurs. D'autre part, son information est dépassée' (ibid.).

${ }^{26}$ R. Gryson, 'Les commentaires patristiques latins de l'Apocalypse', RThL 28 (1997) 305-337; 484-502, e.g. 317: 'K.B. Steinhauser a jeté les bases d'une éventuelle reconstitution'.

${ }^{27}$ E.g. 'On peut se demander si ce laborieux travail d'étudiant, qui n'est guère plus qu'un état de la question, méritait l'honneur d'une publication intégrale. Il n'apporte pas grand-chose de neuf et contient trop d'inexactitudes. L'auteur tranche sans analyse approfondie et sans preuve suffisante des questions dont il ne soupçonne pas la complexité' (17). Etc.

${ }^{28}$ E.g. p. 33; 37; 47 n. 107; 64; etc.

${ }^{29}$ Bedae presbyteri Expositio Apocalypseos, cura et studio Roger Gryson, CCL 121A, Turnhout: Brepols Publishers 2001.

${ }^{30}$ Cassiodori Senatoris Complexiones in Apocalypsin, cura et studio Roger Gryson, CCL 107, Turnhout: Brepols Publishers 2003, 113-129.

${ }^{31}$ All in Commentaria minora in Apocalypsin Iohannis, cura et studio Roger Gryson, CCL 107, Turnhout: Brepols Publishers 2003. In this volume Gryson also provides a new edition of the Commentary of Apringius (bishop of Beja in Portugal, mid-sixth c.), a work which was previously considered to have been influenced by Tyconius, but according to Gryson was not.

${ }^{32}$ Glossa in Apocalypsin e codice Bibliothecae Vniversitatis Catabrigiensis Dd.X.16, cura et studio Roger Gryson, CCL 108G, Turnhout: Brepols Publishers 2013.

${ }^{33}$ Victorini Poetovionensis Opera quae supersunt, cura et studio Roger Gryson, CCL 5, Turnhout: Brepols Publishers 2017.

${ }^{34}$ Beati Liebanensis Tractatus de Apocalypsin, cura et studio Roger Gryson, CCL 107B/107C, Turnhout: Brepols Publishers 2012. 
lost Commentary, together with already existing editions of the homilies of Caesarius of Arles by Dom Germain Morin, ${ }^{35}$ as well as the Commentaries of Ambrosius Autpertus (edited by Dom R. Weber, CCM 27 and 27A) and of Primasius of Hadrumetum (edited by A.W. Adams, CCL 92).

This rather scant overview is clarified in the sequel of Gryson's introduction. Speaking of the sources for his reconstruction of 'Tyconius' Commentary, he discusses the various texts in succession of their rank and ancientness. First come the Budapest Fragments. Fairly recently discovered and for the first time diplomatically edited by Gryson in 1997, ${ }^{36}$ they comprise most of Tyconius' commentary on Apoc. 6:6-13. Their significance, according to Gryson, is not only that they impart Tyconius' original text, but also that they make it possible to see (although on a limited basis) in which manner later commentators handled their source: Caesarius in characteristic brevity; Primasius in a usually free rendering; Bede in full fidelity to his original; Beatus according to his tendency to amply gloss Tyconius, even in a way which is 'often irrelevant or even false'. ${ }^{37}$

In his discussion of the Turin Fragments, Gryson first relates their discovery and editio princeps by Ambroise Amelli in 1897, after which he focuses on Francesco Lo Bue's edition (1963). He provides new and rather long lists indicating (1) where these Fragments differ from passages in other writers who, in his opinion, exactly reproduce Tyconius' wording; and (2) where the author of these Fragments shows that he did not understand Tyconius. Gryson's conclusion is that ' 1$]$ a paraphrase de Turin n'est pas seulement une relecture facilitante, c'est aussi une relecture «catholisante» du commentaire de Tyconius'. ${ }^{38}$ This assessment has a negative bearing on the studies of all those researchers who-as for example Romero Pose in his many publications on Tyconius-considered the Fragmenta Taurinensia to be genuine Tyconian texts. ${ }^{39}$ In spite of the misleading title of his posthumously published book, Lo Bue saw this correctly: 'We cannot at once consider it as a

\footnotetext{
${ }^{35}$ Expositio in Apocalypsim, ed. G. Morin, S. Caesarii Opera Varia ..., vol. II, Maretioli: [s.n.] 1942, 209-277.

${ }^{36}$ See above, n. 6.

${ }^{37}$ Gryson, 'Les sources', in: Tyconii Afri Expositio Apocalypseos, 24: 'Ils [sc. the Fragmenta Budapestiensia] permettent d'observer par comparaison, sur une base limitée, de quelle façon les commentaires dérivés traitent cette source: la brièvité de Césaire, la liberté de Primasius, la fidélité de Bède, la tendance de Beatus à gloser abondamment, souvent hors de propos, voire à faux'.

${ }^{38}$ Gryson, 'Les sources', 33. Cf. e.g. 29: 'C'est une paraphrase, une version «revue et corrigée» du text original'.

${ }^{39}$ Unfortunately the same goes for the-in principle-very helpful concordance composed by Paola Marone, Le concordanze di Ticonio, Pisa-Roma: F. Serra 2009. Gryson is sharp in his verdict ('Les sources', 28 n. 30): 'Rien n'avertit le lecteur que les trois textes amalgamés dans cette concordance ne sont pas de même nature. Les Règles et les fragments du commentaire sur l'Apocalypse retrouvés à Budapest (reproduits sans autorisation de l'éditeur) sont des textes authentiques de Tyconius, tandis que les fragments de Turin sont une paraphrase parfois très libre. Le titre est d'ailleurs doublement illusoire, car il ne s'agit pas d'une concordance, au sens où l'on entend habituellement ce mot, mais d'un index'. Be all that as it may, Marone's 'concordance' nevertheless remains a very useful instrument to see which word appears where in Tyconius' Liber Regularum and Fragmenta Budapestiensia, as well as in the (reworked) Fragmenta Taurinensia.
} 
direct, even though fragmentary reproduction of the original Tyconian work'. ${ }^{40}$ Yet Gryson has much to criticize in Lo Bue's editorial work, and therefore provides his own edition — with brief apparatus criticus and a biblical source apparatus —at the end of his book. ${ }^{41}$ Although one may agree with much of Gryson's criticism, it seems to me that especially Lo Bue's first apparatus in which he indicates the parallels with other commentators, as well as with Tyconius' Liber regularum, remains of lasting value. For linguistic reasons, and because of Augustine's mainly positive assessment of Tyconius, Gryson suspects that these Fragments orginated from North African circles soon after the death of the bishop of Hippo. ${ }^{42}$

The nineteen Caesarian 'sermons'-previously categorized as 'pseudoaugustinian', but since the in-depth research of Germain Morin attributed to Caesarius of Arles - in actual fact consist of reading notes on the Apocalypse (version A), which are more or less ordered to serve as the 'canvas' for a series of expositions (version B). Gryson does not adhere to much of Morin's editorial work and therefore thinks he himself should provide a new edition of these so-called 'homilies'. ${ }^{43}$ As far as I am aware, this plan has not been implemented; in his edition of Tyconius' Commentary, he always refers to Morin's work, which first appeared in 1942.

As is the case with Caesarius, Primasius also should be read with an eye on the apparatus criticus. ${ }^{44}$ Gryson does not have much to comment on Adam's edition of Primasius' Commentary, ${ }^{45}$ but cautions his readers against the 'rearrangements' in the high-quality Oxford ms. that Adams was able to use for the first time. Cassiodorus' Complexiones are considered of little value and thereforenotwithstanding his own new edition ${ }^{46}$ _omitted in Gryson's apparatus of parallel places. He also considers the newly edited Commemoratorium (pseudo-Jerome; second part seventh or early eighth c.) of minor value. His appreciation of Bede's Commentary is otherwise: not only does it explicitly and literally quote Tyconius ten times, but it also adduces his Commentary on innumerable other occasions. According to Gryson, the young Bede is the most faithful attestor to Tyconius' text. Yet it is not Tyconius, but Primasius who is the real conductive thread of

\footnotetext{
${ }^{40}$ Lo Bue, Turin Fragments, 10, quoted by Gryson, 'Sources', 29.

${ }^{41}$ Gryson, 'Appendix Fragmenta Tavrinensia', in Gryson (ed.), Tyconii Afri Expositio Apocalypseos, 347-386.

${ }^{42}$ Gryson, 'Les sources', 34.

${ }^{43}$ Cf. Gryson, 'Les sources', 42.

${ }^{44}$ Gryson, 'Les sources', 46.

${ }^{45}$ Primasius episcopus Hadrumentinus, Commentarius in Apocalypsin, cura et studio A.W. Adams (CCL 92), Turnhout: Brepols 1985.

${ }^{46}$ Auctores varii, Commentaria in Apocalypsin Johannis: Variorvm avctorvm Commentaria Minora in Apocalypsin Johannis, scilicet Apringi Pacensis Tractatus Fragmenta, Cassiodori Senatoris Complexiones, Pavca de Monogramma excerpta, Incerti Avctoris Commemoratorivm, De Enigmatibus ex Apocalypsi, Commemoratorivm a Theodvlpho Avctum, quae omnia recognovit et commentario critico instrvxit Roger Gryson (CCL 107), Turnhout: Brepols Publishers 2003.
} 
Bede's Commentary. ${ }^{47}$ The Cambridge gloss ${ }^{48}$ and some related texts (such as the Commentary in the Paris ms. BNF lat. 15679 ${ }^{49}$ ) are considered to be of some value. The early medieval author Ambrosius Autpertus († 784) relies heavily on Primasius, but sometimes reflects Tyconius better than his main source, and only in these cases is he cited in Gryson's apparatus of parallel sources. Although Beatus—as we saw earlier ${ }^{50}$ - often misunderstands and misquotes Tyconius, his twelve books remain the most important source for reconstructing the Donatist's Commentary. Because Gryson considers the modern editions of Sanders and Romero Pose as completely substandard, he recently provided a new one of his $\mathrm{own}^{51}$ - a major edition that already has a key function in the present book.

In his third chapter, Gryson further addresses the problem of how to reconstruct Tyconius' lost Commentary. In line with Ramsay, he considers Beatus - who also made use of Victorinus in Jerome's version and Apringius-his pivotal source and, thus, his starting point for reconstruction. Electronic databases allow us to detect which parts in Beatus' commentary came from other sources. Gryson however grants that, in some cases, Beatus could have made use of texts that are either not yet included in these databases, or will remain unknown; ${ }^{52}$ besides, there may be passages authored by Beatus himself. ${ }^{53}$ Yet Gryson is confident that, based on Beatus' handling of his apparent sources, he can deduce Beatus' handling of 'Tyconius as well. Moreover, it appears essential to have a thorough knowledge of, for instance, the style and points of interests of those other sources. ${ }^{54}$ Gryson additionally argues that - in view of the many extra pages needed - it is impossible to explain in each case why the wording he chose for his reconstruction of Tyconius' Commentary is as it is. ${ }^{55}$ With words of Jerome he concludes: Etiamsi ego taceam, prudens lector intellegit. ${ }^{56}$

As regards the reconstitution of the lemma, Gryson remarks that many of those who followed Tyconius' Commentary did not follow his biblical text: Primasius offers an African text, most probably the one in use in his Hadrumetum

\footnotetext{
${ }^{47}$ Some years ago, Gryson provided a new edition of Bede's Expositio Apocalypseos; see above, n. 29. This edition is more or less outdated, however, because among the source texts on the left pages 'Tyconius' could only be represented by his supposed epigones in (in the meantime) partially obsolete editions.

${ }^{48}$ Recently edited by Gryson in CC $108 \mathrm{G}$; see above n. 32 .

${ }^{49}$ Recently edited by Gryson as well in CC 107, 305-377: cf. above n. 31.

${ }^{50}$ See n. 37.

${ }^{51}$ See above, n. 34.

${ }^{52}$ Gryson, 'La présente édition', in: Tyconii Afri Expositio Apocalypseos, 75.

${ }^{53}$ Gryson, 'La présente édition', 75.

${ }^{54}$ Gryson, 'La présente édition', 76: 'Le lecteur doit savoir qu'il ne suffit pas, pour se faire une opinion sur celle-ci [i.e., on the parallels in the other commentaries indicated in his first apparatus], de les comparer rapidement. Il faut avoir au préalable étudié attentivement chacun de ces commentaires et s'être familiarisé avec les tours de langue, les procédés de composition, les centres d'intérêt et les idées propres à leurs auteurs. On ne peut faire l'économie de cet effort sans s'exposer à des lourdes méprises'.

${ }^{55}$ Gryson, 'La présente édition', 76-77.

${ }^{56}$ Gryson, 'La présente édition', 78, quoting from Jerome’s Commentary on Malachi.
} 
church; Cassiodorus follows an African text which is close to Primasius; the Cambridge gloss, Bede and Ambrosius Autpertus comment on the Vulgate. Based on the Turin Fragments ${ }^{57}$ in particular, but also from many passages in Caesarius and Beatus (although both show the influence of the Vulgate), Gryson describes 'Tyconius' text (siglum S) as being, in all probability, an ad hoc text. Interestingly, in Apoc. 13:8 this text may have read esphragismenou for esphagmenou: according to Tyconius the lamb was signati, not occisi.

The question of the division of Tyconius' Commentary leads to its essence. According to Tyconius, John's Apocalypse does not provide a progressive history of the Church, but tells its story from Christ's first advent until his second coming as a repetitive series of events. This repetitive regress to its beginning ( $s c$. the birth or passion of Christ) is a key exegetical principle in Tyconius' Liber regularum, especially in reg. VI: De recapitulatione. John describes successive visions, not successive events. ${ }^{58}$ The principle of recapitulatio leads to a division of John's book in seven sections (periochae), with the fourth divided into ten smaller units (capitula). Gryson, in his edition, strictly follows this seven sections division. As regards the number of books of 'Tyconius' Commentary, he suspects there were three, as in the case of Bede's Commentary (and not twelve, as in the case of the long-winded Beatus).

As for the core of the book, sc. Gryson's reconstructed text (103-228), I prefer to be brief. This edition of Tyconius' Commentary is in full accordance with the principles the editor set out in his extensive introduction. As far as I am aware the Latin text is faultless, and the same goes for the two apparatus. Although one may differ on readings such as Israelita (139) in stead of Israbelita ${ }^{59}$ or diabolum (140) for diabulum, ${ }^{60}$ this is - in all respects - a scientific work of the highest level. For the first time ever, we have a complete and reliable reconstruction of Tyconius' lost work, fully arranged according to his exegetical principles, clearly indicating his biblical quotes and allusions, and with the sources on which the reconstruction is based easily visible and chronologically ordered in the first apparatus at the bottom of the page.

It is difficult to resist the temptation to quote many a passage from this masterpiece of patristic biblical interpretation. I mention only two typical ones. In the first, Tyconius expresses his conviction that, often (!), the Holy Spirit obscured the meaning of a text in order to stimulate the reflection of the reader: Frequenter enim spiritus sanctus aliter quam proponit breniter enarrat et finito eo quod ad obscurandum interposuerat, ad propositum redit: 'For frequently the Holy Spirit briefly explains something that he announces in a different way, and after what he had inserted to

\footnotetext{
${ }^{57}$ But see below at n. 70 .

${ }^{58}$ Cf. e.g. Tyconius, Exp. Apoc. 2,1 (CCL 107A, 129): 'Diuersum tempus non gestorum, sed uisionum est', litt.: 'The different time is not the time of the events but of the visions'.

${ }^{59}$ Cf. Tyconius, reg. 2,13; 3,2,2.

${ }^{60}$ Cf. Gryson, 'Fragments inédits' [n. 6], 225.
} 
obscure [the meaning] is completed, he returns to an announcement ${ }^{61}$ My second example relates to a noted apocryphon: «qualem enim inuenerit dominus, cum uocat, talem et indicats: "For "such as the Lord will find when he calls, such also he will judge". ${ }^{62}$ Although the agraphon in this and several related forms has been well known in Christian circles since Justin Martyr, Clement of Alexandria, and Cyprian, ${ }^{63}$ one may suppose that its quotation by Tyconius (which is reflected in the commentaries of Caesarius and Beatus) has contributed significantly to its diffusion during the Middle Ages and beyond.

As for Gryson's 100 pages of 'Notes complémentaires', I notice that many of them concern the reconstruction of the text and related linguistic problems. These cases in particular indicate that Gryson's preparation of an edition of the ancient Latin versions of John's Apocalypse was at the background of the entire project. ${ }^{64}$ Another obvious aspect of these 'Notes' is that they frequently indicate where and how Tyconius' exegesis puts the principles of his Liber regularum into practice. Gryson also shows that he is an excellent patristic scholar by adducing many parallels from ancient Christian writers such as Jerome, Augustine, and several others. On the basis of remarks in the Commentary $(1,11 ; 3,38 ; 4,46 ; 5,18)$ it is clear to him that Tyconius knew Greek. A special point of interest is that, according to Tyconius' Bible text, the mysterious number of the Beast was 616.

The edition is completed by an 'Index scripturaire' (339-345) and-as already indicated above- by a new edition of the Turin Fragments (but without any index).

\section{Gryson's Translation of Tyconius' Reconstructed Commentary}

Although there is some overlap with the text edition, Gryson's French translation with considerably long 'Introduction' (9-58), many elucidating footnotes, and concluding 'Index scripturaire' (215-220) has a value of its own. It may be welcomed as very helpful aid in understanding Tyconius' Latin text, and also as highly valuable in illuminating its meaning. Gryson starts by briefly introducing Tyconius before he elaborates on 'the language of the Spirit', detailing, for instance,

\footnotetext{
${ }^{61}$ Tyconius, Exp. Apoc. 3,2 (CCL 107A, 152). Cf. 1,11 (CCL 107A, 111): ‘... multo magis obscurandae rei gratia ...'; 2,16 (CCL 107A, 133): ' SIGNATVM SIGILLIS SEPTEM [Apoc. 5:1], id est omni mysteriorum plenitudine obscuratum'; 5,4 (CCL 107A, 190): '... sed unam rem diuidit obscurandae rei causa'. For the principle, cf. e.g. reg. 4,1: 'Sed loquimur secundum mysteria caelestis sapientiae magisterio Spiritus Sancti [cf. 1 Cor. 2:4,5,7], qui cum ueritatis pretium fidem constituerit mysteriis narrauit in speciem genus abscondens ...'.

${ }^{62}$ Tyconius, Exp. Apoc. 4,49 (CCL 107A, 188).

${ }^{63}$ Cf. e.g. J.K. Elliott, The Apocryphal New Testament, Oxford: OUP 1993 (repr. 2005), 30, who refers to Justin, Dial., 47, 'Clement and many others', and also remarks in a note: 'J.H.

Charlesworth, The Old Testament Pseudepigrapha, i, Apocalyptic Literature and Testaments (London, 1983) includes this (p. 495) as a fragment of the Apocryphon of Ezekiel'.

${ }^{64}$ Gryson, 'Introduction', in: Tyconii Afri Expositio Apocalypseos, 7; cf. Gryson, 'Les commentaires' [n. 26], 305: 'Dans la perspective d'une future édition de la Vetus Latina de l'Apocalypse, nous nous proposons de faire ici le point concernant les nombreux problèmes de critique que soulèvent ces ouvrages'.
} 
its 'subtlety': nothing is without reason, and much deliberately obscured on account of the many digressions, recapitulations, synonyms, and distinctions between genus and species. The unique subject of the Apocalypse is the Church, the body of Christ, and most of Tyconius' Regulae find their exegetical application in this book. The Apocalypse not only deals De domino et corpore eius (reg. 1), but also abundantly proves that this body is 'bipartite' (De domini corpore bipertito, reg. 2) and that the devil has his own body (De diabolo et eius corpore, reg. 7). Moreover, what has been stated about the principle of 'recapitulation' (De recapitulatione, reg. 6) and of 'times' (De temporibus, reg. 5) is widely applied in the Commentary. The 1000 years of Apoc. 20:4 and 6 is the remaining part of the sixth millennium of world history since the time of Christ's advent (cf. reg. 5,3). This idea, accepted by Augustine, put an end to most 'millenarian' expectations in the Latin Church. The essence of Tyconius' Commentary is that he did not consider the Apocalypse an eschatology, but an ecclesiology: Nibil est enim quod praeter ecclesiam describat. ${ }^{65}$

\section{An Evaluation of Gryson's Achievement}

It may be evident from the preceding that, all in all, I am impressed with Gryson's achievement. His work of many years has reached its peak in the reconstruction of Tyconius' lost Commentary and its highly expert explanation and interpretation. Even so, one is left with some hesitation and doubt regarding this reconstruction. A weak point in Gryson's modus procedendi is, in my view, his valuation of Beatus' Commentary, since many parts of it cannot be identified with certainty as they may belong to Beatus himself, or derive from unknown sources. Besides, there are many uncertainties about the actual contents of Caesarius' sermons. Moreover, can we be sure that Tyconius made use of the Commentary of Victorinus; and-if so-to what extent? One finds the idea of 'successive sequences', which retake each time the thread of history, already in Victorinus' Commentary; it is, however, also the leading principle described as recapitulatio in Tyconius' reg. VI.

Still in 1997, Gryson wrote: 'Est-il possible de reconstituer le commentaire de Tyconius sur l'Apocalypse à partir des fragments conservés et des commentaires ultérieurs, qui s'en sont largement inspirés? Ce n'est pas sûr'. ${ }^{66}$ A number of years later, however, he seems convinced that a reconstruction is fully possible, be it with some minor restrictions. It might be, so Gryson, that at one point in the future a manuscript of the original will be discovered (although he considers this increasingly less probable since the medieval manuscripts are better inventorised and better described). 'Et si l'on découvrait un jour quelque fragment superposable au texte reconstitué, quelle belle confirmation ce serait de la validité des principes et des méthodes de la critique littéraire!. ${ }^{67}$ In view of the fact that many texts that had been considered to be definitively lost or that were even previously unknown have been discovered in recent years, I think it is better to remain reserved. It is well

\footnotetext{
${ }^{65}$ Tyconius, Exp. Apoc. 2,49 (CCL 107A, 149).

${ }^{66}$ Gryson, 'Les commentaires' [n. 26], 316.

${ }^{67}$ Gryson, 'Introduction', in: Tyconii Afri Expositio Apocalypseos, 8.
} 
known that, in the ninth century, the monastery of St. Gallen still owned a copy of Tyconius' Commentary. ${ }^{68}$ Besides, Gryson himself knows better than anyone else about the discovery of the Fragmenta Budapestiensia and their contribution in regaining the 'original' Tyconius. ${ }^{69}$

Some minor criticism may also be expressed. It is a pity that the arrangement of 'Tyconius' reconstructed Commentary in seven sections is not clearly reflected in the 'running title' of the pages of the French translation. While browsing and reading through the translation, it is with difficulty that one finds the exact place in the Latin Commentary. As regards this edition, it is not userfriendly to refer to another book for patristic abbreviations, sc. Gryson's Répertoire général des auteurs ecclésiastiques latins de l'Antiquité et du Haut Moyen Âge (Vetus Latina 1/1, Freiburg 2007). Nevertheless, one gets far with a good general knowledge of patristic literature and-luckily — the help of Gryson's list of 'exceptions' on p. 11. In his list of 'other abbreviations', one stumbles upon the curious 'CV', which in Gryson's sometimes idiosyncratic manner of referencing appears to be the 'Corpus Vindobonense', commonly known as CSEL (and now based in Salzburg).

Other minor points of criticism-which may be corrected in a later edition-comprise the following. After having stated that Primasius used the text of the African Bible read, in all probability, in his Hadrumetum church, while Cassiodorus also used an African text, and the medieval glosses as well as Bede and Ambrosius Autpertus commented on the Vulgate, Gryson remarks: 'Restent donc comme témoins du texte de Tyconius la paraphrase de Turin, Césaire et Beatus, auxquels il faut ajouter des variantes citées occasionnellement par Primasius et Bède' (79-80). I miss in this list the testimony of the Fragmenta Budapestiensia, which contain some 25 Bible quotes and allusions. ${ }^{70} \mathrm{With}$ reference to these same Fragments, one may question Gryson's reconstruction of Tyconius' Commentary on p. 141, including a quotation from Joel 2:4.5: 'Sicut uisus equorum facies eorum, sicut equi ita persequenter, et sicut nox currum super uertices'. Both in Gryson's diplomatic edition and in his reconstituted text, this reads: 'Sicut v[isus ****] s equorum fa [c]ies [eo]rum, [si]cut equi ita persequenter, [et sicut vo]x [curruum] super vertices. ${ }^{71}$ In his reconstruction, Gryson follows Beatus and not the highly respected Budapest Fragments. The pseudo-Augustinian Liber de diuinis scripturis is not the same as Augustine's genuine Speculum (313; 318; 319). Some translations of Tyconius' Expositio in the 'Notes complémentaires' overlap with the translations in Tyconius, Commentaire de l'Apocalypse; sometimes they show differences, but in all these

\footnotetext{
${ }^{68}$ J. Haussleiter, 'Die Kommentare des Victorinus, Tichonius und Hieronymus zur Apokalypse', ZKWL 7 (1886) 239-257 (240-241), with reference to G. Becker, Catalogi bibliothecarum antiqui, Bonn 1885.

${ }^{69}$ Cf. Gryson, 'Fragments inédits' [n. 6].

${ }^{70}$ Cf. Gryson, 'Fragments inédits', 226.

${ }^{71}$ Gryson, 'Fragments inédits', 198-199 and 225. Gryson's reference here is only to Joel 2:4; in Tyconii Afri Expositio Apocalypseos, 141, he mentions the more likely reference Joel 2:4.5.
} 
instances I prefer the translation given in the second case. ${ }^{72}$ As far as I can see, the reference on p. 39 ('voir ci-dessous p. 232') leads to nothing; n. 53 on p. 97 should run: 'Voir ci-dessous p. 301-302'.

In many instances, Gryson shows himself less certain than in the just quoted sentence from the 'Introduction'. ${ }^{73}$ Elsewhere he rightly states that reconstitution work such as this 'ne peut aboutir qu'à des résultats approximatifs'.$^{74}$ Many times he sees himself obliged to correct earlier statements, ${ }^{75}$ in particular as regards his previous work on the early Latin text of the Apocalypse, ${ }^{76}$ which in many respects has been basic to his present work. One might say that-like Augustine-he is making progress when writing, and writing when making progress. ${ }^{77}$ In the given circumstances, this reconstruction of Tyconius' Commentary is the best result that could be achieved and, without a doubt, the best person who could achieve this is Roger Gryson.

\section{Tyconius' Exposition of the Apocalypse in English}

Fairly soon after the publication of Tyconii Afri Expositio Apocalypseos, Francis X. Gumerlock and David C. Robinson produced their English translation with introduction and notes. ${ }^{78}$ This is a fine accomplishment as well. Robinson's 'Introduction' in four paragraphs outlines the research on Tyconius' Exposition of the Apocalypse, stresses the importance of his seven 'mystic rules', and gives a summary of these rules. According to Robinson, ' $[\mathrm{t}$ ] he Book of Rules should be read before reading the commentary, and the commentary should be read hand-in-hand with the Book of Rules. ${ }^{79}$ When discussing the main contents of the Commentary, Robinson further states that, according to Tyconius, '[t]he Apocalypse is the revelation of the church's internal and external spiritual warfare' ${ }^{80}$ Summarizing his introductory overview, he aptly remarks: 'Tyconius applies the logic of the seven

\footnotetext{
${ }^{72}$ Cf. e.g. 'la prédication circulant au sein de l'Église' (98) with the idiomatically better translation: 'la prédication diffusée au sein de l'Église' (189).

${ }^{73} \mathrm{Cf}$. main text belonging to n. 67 above.

${ }^{74}$ Gryson. 'État de la question', in: Tyconii Afri Expositio Apocalypseos, 16. Other statements proving Gryson's uncertainties are, for instance: 'Tyconius vise peut-être ici Victorin ...' (303); ‘... j’ai suivi Beatus, non sans hésitation ...' (308); 'Il est possible que Tyconius ait lu dans sa Bible ... Il est possible également ...' (309).

${ }^{75}$ Gryson, 'Notes complémentaires', in: Tyconii Afri Expositio Apocalypseos, e.g. 332 n. 88: 'Dans Vetus latina, t. 12, p. 703, je fais l'hypothèse ... Cela n'explique pas ... Cela ne prouve pas ...'. ${ }^{76}$ Gryson, 'Notes complémentaires', in: Tyconii Afri Expositio Apocalypseos, e.g. 260: 'J'ai eu tort ... dans mon édition de l'Apocalypse (Vetus Latina, t. 26/2)'; 263: 'J'ai fait erreur, dans mon édition de l'Apocalypse ...'; 264: '... j'ai fait un mauvais choix, dans mon édition de l'Apocalypse ...'; 275: 'Erreur de ma part dans l'édition de la Vetus Latina de l'Apocalypse...'; 307: 'Erreur de ma part dans Vetus Latina, t. 26/2 ...'; ‘... contrairement à ce que j’ai écrit dans mon édition de l'Apocalypse ...'.

${ }^{77}$ Cf. Aug., ep. 143,2.

${ }^{78}$ Cf. n. 3 above.

${ }^{79}$ D.C. Robinson, 'Introduction', in: Tyconius, Exposition of the Apocalypse, 6.

${ }^{80}$ Robinson, ibidem, 16.
} 
mystic rules throughout his commentary on the Apocalypse. He discerns referents to the Lord, his body, and the union of the two; he distinguishes referents to the left and right parts of the bipartite church; he affirms the certainty and explains the conditions of divine promises; he notes the dynamic relationship between the species and genus; he recognizes and interprets the mystic significance of temporal quantities; he explains both literary and mystical modes of recapitulation; and, finally, he discerns the masquerading activity of the devil and his body'. ${ }^{81}$

One comes upon all these features when reading through the very lucid translation. Gumerlock's rendering reads very easily and is an achievement in its own right, complemented by Robinson's expert notes. Following Gryson, the authors have divided Tyconius' Commentary into seven sections, which they call (rather misleadingly) 'books'. The running title of the translation pages indicates the chapter and verses of Revelation commented upon, which in itself is useful, although it creates the impression that Tyconius composed a verse-by-verse commentary in the manner of most modern exegetes. The reader's convenience is further served by two excellent indices: one comprehensive 'General Index' on names and subjects; the other an 'Index of Holy Scripture'. From the last index, one learns at a glance how often Tyconius discusses OT texts, while closer examination reveals that, from the Gospels, he never (or nearly never) quotes Mark. ${ }^{82}$

The only two printing errors I stumbled upon are in the beginning: Forster (XIV) should read Förster; Aogostino is, of course, Agostino (same page). It is interesting to see the 'Augustinian' idea of 'we are the times: such as we are, so are the times ${ }^{93}$ already in Tyconius: '... days are not able to be evil, but people who are in days are evil'. ${ }^{84}$ Gryson rather extensively discussed the problem of how to translate Tyconius' term praepositi, and he finally opted for 'dirigeants'; ${ }^{85}$ Gumerlock translates 'bishops' ${ }^{86}$ I think that French 'conducteurs' (cf. Segond's translation of begoumenoi in Hebr. 13:7.17.24), 'préposé' or perhaps even 'pasteurs' ${ }^{87}$ would fit better; Gumerlock's 'bishop' might be replaced by 'pastor'. The term praepositus

\footnotetext{
${ }^{81}$ Robinson, ibid., 22-23.

${ }^{82}$ Although the index indicates seven instances in which $\mathrm{Mk}$ is brought up, none of these cases is a literal quote. The same struck me in Tyconii Afri Expositio Apocalypseos. In actual fact there is no unequivocal quote from $\mathrm{Mk}$, because the only instance in which there seems to be a quote, the same biblical words also occur in the (often cited) Mt.

${ }^{83}$ Cf. Aug., s. 80,8: 'Bene vivamus et bona sunt tempora. Nos sumus tempora; quales sumus, talia sunt tempora'.

${ }^{84}$ Tyconii Afri Expositio Apocalypseos, 106: '... et dies mali sunt [Eph. 5,16], cum dies mali esse non possint, sed homines sunt mali, qui in diebus sunt'.

${ }^{85}$ Gryson, 'Introduction', in: Tyconius, Commentaire de l'Apocalypse, 43-44. He introduces his discussion with the apt remark: 'Notons que les mots clerus (et ses dérivés), minister (et ses dérivés), episcopus, presbyter, diaconus, ne font pas partie du vocabulaire de Tyconius. Quant à sacerdos, il ne s'applique chez lui, comme dans les textes chrétiens des deux premiers siècles, qu'aux prêtres de l'Ancien Testament et aux fidèles dans leur ensemble. La seule fonction qu'il connaisse est celle des praepositi'.

${ }^{86}$ See e.g. Tyconius, Exposition of the Apocalypse, 48.

${ }^{87}$ Cf. e.g. Blaise, s.v. praepositus.
} 
seems to indicate nothing more or less than this prime pastoral function. In any case, in Tyconius' view of church offices (officia), there seems to be no trace of superiority (so no 'chef') or hierarchy (no 'bishop' in the usual Catholic or Donatist sense of the word).

\section{Tyconius as the Source of the Augustinian Concept of the Two Cities?}

Now that, with these new publications, Tyconian studies have entered a new phase, the old issue of the 'real' source of Augustine's doctrine of the duae civitates has reemerged as well. In his translation of Tyconius' Commentary, Gryson enters the problem rather extensively. He remarks: 'Il y a, en effet, deux cités dans le monde, une qui appartient à Dieu, l'autre qui appartient au diable. L'une descend des cieux, tandis que l'autre monte de l'abîme; celle-ci est représentée de manière emblématique par la Babylone biblique’. ${ }^{88}$ In the corresponding note, Gryson refers to four passages in his edition of Tyconius' Expositio Apocalypseos and states: 'La question de savoir si Tyconius pourrait être à l'origine de la conception augustinienne des deux cités (...) mériterait d'être revue à la lumière du commentaire de l'Apocalypse'. ${ }^{89}$

From the four passages referred to by Gryson to underscore his opinion, two relate specifically to the idea of two opposed cities. The first one is Tyconius' (reconstructed) commentary on Apoc. 14:8. Here it runs in the first part: 'ET ANGELVS SECVNDVS SECVTVS EST, id est pacis futurae praedicatio, DICENS: CECIDIT, CECIDIT BABYLON ILLA MAGNA. Babylonem ciuitatem diaboli dicit, id est populum ipsi consentientem et omnem corruptelam quam in perniciem sui et humani generis exquirit. Nam sicut ciuitas dei ecclesia est, ita e contrario ciuitas diaboli Ierusalem est et Babylon in omni mundo, sicut dominus dicit: Ecce pono Ierusalem lapidem conculcabilem in omnibus gentibus' ${ }^{90}$ 'The second one is in Tyconius' explanation of Apoc. 17:18: 'Duae sunt enim in mundo ciuitates, una dei et una diaboli, una de abysso, altera de caelestibus oriens'. ${ }^{11}$ The other two passages only speak of the ciuitas diaboli. ${ }^{92}$

At first glance, the just quoted passages seem essential. In John's Apocalypse, however, the two antithetical cities Jerusalem and Babylon play such a central role that every explanation will emphasize the existence of these two civitates. They belong to the core of its imagery. The same goes for the concepts of the

\footnotetext{
${ }^{88}$ Tyconius, Commentaire de l'Apocalypse, 44.

${ }^{89}$ Tyconius, Commentaire de l'Apocalypse, 44-45, n. 71.

${ }^{90}$ Tyconii Afri Expositio Apocalypseos, 189 (5,3,1-13).

${ }^{91}$ Tyconii Afri Expositio Apocalypseos, 209 (6,21,6-8).

${ }^{22}$ Tyconii Afri Expositio Apocalypseos, 209 (6,22,11-13): 'Nulla est ciuitas quae omnem animam immundam capiat, nisi ciuitas diaboli, in qua omnis immunditia per orbem commoratur'; Tyconii Afri Expositio Apocalypseos, 210 (6,25,13-16): '... quomodo particeps peccati esse potest iustus quem cum impiis ciuitatis casus abstulerit, nisi ciuitati diaboli aperta discessione celebrata notam bestiae portaturus insidiat?'
} 
church as the civitas dei and its worldly counterpart as the civitas diaboli: they naturally belong to the metaphorical language of Revelation.

Traugott Hahn, in his Tyconius-Studien quoted above, already in 1900 referred to passages in Beatus which might prove that Tyconius could be the forerunner of Augustine's doctrine of the two civitates. ${ }^{93}$ These passages come even closer to Augustine's doctrine than the just quoted ones, but Hahn was very cautious not to state that Tyconius was simply the source of Augustine's doctrine. ${ }^{94}$ He was very well aware of the status of Beatus' text, seeing that the Spanish monk was thoroughly acquainted with, for instance, the writings of Augustine. Heinrich Scholz, in his very influential Glaube und Unglaube in der Weltgeschichte, repeated Hahn's cautious conclusion, ${ }^{95}$ but at the same time he and his many followers went a step further. In their view, Tyconius was the source of Augustine's doctrine of the two civitates, and Beatus had provided the proof.

In my 1986 book Jerusalem and Babylon, I discussed in detail not only the numerous researchers who-in the wake of Scholz in particular-considered Tyconius' Commentary the (principal) source of inspiration for Augustine' doctrine of the duae civitates, but also those who especially referred to Tyconius' Liber regularum. ${ }^{96}$ With regard to the latter possibility, I note that also Jean-Marc Vercruysse, in a 'note complémentaire' in his book on Tyconius' Liber regularum, ${ }^{97}$ stresses the differences between Tyconius' notion of corpus and Augustine's concept of civitas.

Now as well, with the groundbreaking edition of Gryson at hand, it must be remarked that Augustine's doctrine of the two civitates includes so much more than just the opposition of the two cities Jerusalem and Babylon. He described world history, from its very beginning in the angel world, as the history of two absolutely antithetical cities. He emphasized that the two cities (civitates) are two societies

\footnotetext{
${ }^{93}$ See Hahn, Tyconius-Studien [n. 12], 25 n. 1, where he quotes Beatus, In Apoc., ed. Florez, 506, 2630 ('Ecce duas civitates, unam Dei, et unam diaboli ... et in utrasque reges terrae ministrant') and ibidem, $29 \mathrm{n}$. with his quote from Beatus, In Apoc., ed. Florez, 507, 15-33 ('perspicue patet duas civitates esse et duo regna, et duos reges, Christum et diabolum: et ambo super utrasque civitates regnant. ... Hae duae civitates, una mundo, et una desiderat servire Christo: una in hoc mundo regnum cupit tenere, et una ab hoc mundo fugere: una tristatur, altera laetatur: una flagellat, altera flagellatur; una occidit, altera occiditur: una ut justificetur adhuc, altera ut impie agat adhuc. Hae utraeque ita laborant in unum, una ut habeat unde damnetur, altera ut habeat unde salvetur'). ${ }^{94}$ Only at the end of his Tyconius-Studien, one reads (115): 'Beide [sc. Augustine and Tyconius] stellen eine civitas Dei und civitas diaboli einander gegenüber'.

${ }^{95}$ H. Scholz, Glaube und Unglaube in der Weltgeschichte. Ein Kommentar zu Augustins De civitate Dei, Leipzig: J.C. Hinrichs'sche Buchhandlung 1911 (several reprints), 79: 'Dadurch wird die Vermutung nahegelegt, dass er [sc. Augustinus] vielleicht auch den entscheidenden Anstoss zu seiner Zweistaaten-Konzeption von Ticonius empfangen hat'. In the rest of the book, it does not appear that it was only a 'conjecture'.

${ }^{96}$ English translation: J. van Oort, Jerusalem and Babylon. A Study of Augustine's City of God and the Sources of his Doctrine of the Two Cities, Leiden-New York-København-Koln: E.J. Brill 1991 (repr. Leiden-Boston: Brill 2013), 262-263.

${ }^{97}$ Cf. Vercruysse, Tyconius, Le Livre des Règles [n. 9], 382-384 (= 'Note complémentaire 2: Tyconius est-il à l'origine de la conception augustinienne des deux cités?')
} 
(societates) which consist of two kinds of people, angels and kings. His doctrine of the two cities was part and parcel of his catechetical instruction. Neither of these elements are found in Tyconius. What I did find, however, was a broad preAugustinian tradition in which the concept of two cities was present. ${ }^{98}$

The most one can say is that Tyconius, in his explanation of John's Apocalypse, stood in this broad tradition of Jewish-Christian testimonies of a doctrine of two civitates. Augustine, who only at a late stage of his career testifies that he had read his Commentary, ${ }^{99}$ may have received an extra stimulus for the development of his Two Cities theory from this book of the 'Reformdonatist'. ${ }^{100}$

\footnotetext{
${ }^{98}$ Cf. Jerusalem and Babylon, esp. 274-359.

${ }^{99}$ Sc. in doctr. chr. 3,42; cf. above n. 4 and, for a full quote, Jerusalem and Babylon, 273 n. 406. It may be recalled that the first draft of doctr. chr., dating from ca. 395, comprised the first two books but broke off after 3,35; the rest was only completed in the late 420 s.

${ }^{100}$ The term 'Reformdonatist' as in Hahn, Tyconius-Studien, 110 n. 1.
} 